九州大学学術情報リポジトリ

Kyushu University Institutional Repository

Historical Development of Rice Paddy Irrigation System and Problems on Water Management in Recent Years : Yamada Diversion Dam Command Area in Japan

Yuge, Kozue

Department of Bioproduction Environmental Sciences, Faculty of Agriculture, Kyushu University

Anan, Mitsumasa

Takasaki Sogo Consultant Co., Ltd.

Nakano, Yoshisuke

Emeritus Professor of Kyushu University

https://doi.org/10.5109/10095

出版情報：九州大学大学院農学研究院紀要. 53 (1)，pp.215-220，2008-02-28. Faculty of Agriculture, Kyushu University

バージョン：

権利関係 : 


\title{
Historical Development of Rice Paddy Irrigation System and Problems on Water Management in Recent Years - Yamada Diversion Dam Command Area in Japan-
}

\author{
Kozue YUGE*, Mitsumasa ANAN ${ }^{1}$ and Yoshisuke NAKANO ${ }^{2}$ \\ Laboratory of Irrigation and Water Utilization, Division of Regional Environment Science, \\ Department of Bioproduction Environmental Sciences, Faculty of Agriculture, \\ Kyushu University, Fukuoka 812- 8581, Japan \\ (Received November 9, 2007 and accepted November 30, 2007)
}

\begin{abstract}
Productivity of rice in Japan has been increased rapidly by the land consolidation of rice paddy area. Modernized irrigation systems have been introduced to improve the irrigation and drainage efficiency. On the other hand, restriction of excessive rice production policy started in 1970 has brought the changes of exquisite water management once accomplished. Additionally, the increasing number of part time farmers has affected the characteristics of water management. To clarify the recent changes of water management, a typical rural area was selected. First, historical development of the rice paddy area supported by the Yamada diversion dam was studied. Second, characteristics of water management in 1981 and 1998 were discussed. The components of lot water requirement and delivery water requirement have shown drastic change, though water consumption rate has shown no change. Third, water intake rate changes at the Yamada diversion dam were studied. It is intersecting to note that the reduced area of rice paddy did not affect the water intake rate to this command area. This result would be caused by the need for keeping the water level in canals to deliver water adequately to each rice paddy fields and by the need for supplying water for increased lot water requirement.
\end{abstract}

\section{INTRODUCTION}

Water uptakes for rice paddy irrigation in main rivers are restricted by the River Act. on their water utilization. In Japan, about $88.9 \%$ of irrigation water is taken following by the traditional right, and remaining $11.1 \%$ is following newly approved water intake right. The command area supplied by the traditional water intake right is $48.3 \%$ and supplied by newly approved water uptake right is $51.7 \%$. The water managements in rice paddy area have been affected by the restriction of excessive rice production policy started 37 years ago. Land consolidation and improvement for developing the modernized agriculture, decreasing number of full time farmers and increasing number of aged farmers are other factors affecting the water management. It is a matter of argument to make clear the reasonable amount of water intake rate for rice paddy area in the changing situation. In this report, historical development of a typical rice paddy area supplied water by the Yamada diversion dam, originally constructed about 400 years ago is introduced. The amount of water intake in this command area is protected by the traditional right, but recently, it is requested to allocate water to other sectors. Some studies were conducted to determine the reasonable amount of intake water in close to this area (Anan et al., 2004). As pointed in their reports, it is necessary to make clear the factors affecting the water management for allocating limited water to other sectors. The roles of irrigation water are not only for supplying consumed water, but also for supporting rice farming and for keeping water level for

TAKASAKI Sogo Consultant Co.Ltd.

Emeritus Professor of Kyushu University

* Corresponding author (E-mail: yuge@bpes.kyushu-u.ac.jp) delivering. For better water allocation in the future, the changes of water management components during about 20 years are discussed.

\section{GENERAL REAMARKS OF STUDY AREA}

The Chikugo River is located northern Kyushu, Japan. Total length of this river is $143 \mathrm{~km}$ and catchments area is $2,860 \mathrm{~km}^{2}$, which is mostly composed of mountainous area. Many dams and diversion dams were constructed for supplying water to rice paddy area and to urban area as shown in Fig. 1. Diversion dam named Yamada is located about $55 \mathrm{~km}$ from the Ariake sea. The water is delivered to command area about 600 ha through main canal with $12 \mathrm{~km}$ and branch and tertiary canals about $20 \mathrm{~km}$. The number of farmers decreased about $18.2 \%$ during these 10 years. The percentage of farmer over 65 years old is $48.6 \%$ and the percentage is still increasing. The percentage of full time farmers is

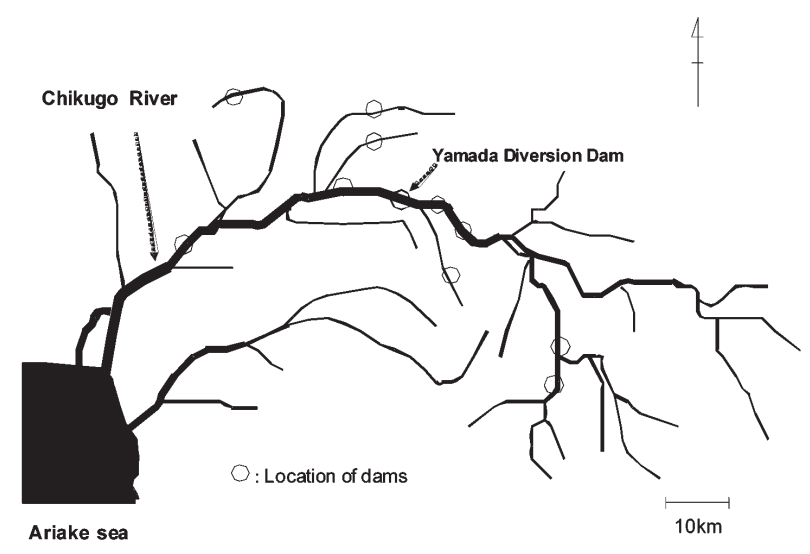

Fig. 1. Dams and diversion dams along the Chikugo River. 
25.1\%. Main agricultural products in this area are rice (46.2\%), wheat (32.2\%), barley (11.7\%) and grass for live stocks (6.4\%).

\section{HISTORICAL DEVELOPMENT OF RICE PADDY AREA}

The Yamada diversion dam was constructed in 1663 with rocks. The total length of dam was $330 \mathrm{~m}$ with passages for rafts and ships as shown in Fig. 2. At the same time, main irrigation canal named Horikawa length about $8,500 \mathrm{~m}$ was constructed for supplying water to 150 ha of rice paddy area. The stone monument shown in Fig. 3 is the bench mark for surveying the area at that time. After 60 years, new project was started to reform the intake gate because the sedimentation of gravels in front of gate impeded the water flow. At the same time main irrigation canal was extended. When the project was ended in 1760, total command area became about 370 ha. After the heavy draught happened in 1782, old diversion dam was slightly reformed to develop more water. In 1789, new plan to develop to increase water intake rate for overcoming heavy draught was proposed by a village headman. But farmers in the lowest level area protested because they were afraid of damages by water logging. Succeeding to get the support of local government, the plan was started in 1790 and ended in 1825. The water logging problems were cleared by the drainage devices. In 1874, the dam was seriously damaged by the big flood. Almost one third of dam $8100 \mathrm{~m}^{2}$ was broken. In 1885, the dam was seriously damaged again by the big flood, and about $8700 \mathrm{~m}^{2}$ were broken. In 1953, the command area about 700 ha was flooded and irrigation canal system was seriously damaged. In 1955, the dam was seriously damaged again by the flood. Every time the dam was damaged, the farmers repeatedly repaired it within one year.

Many wooden waterwheels have been installed along the irrigation canal led from the Yamada diversion dam, for irrigating rice fields which could not be irrigated by gravity flow. Fig. 4 shows one of the historical triple linked waterwheels which pumps up $7,892 \mathrm{~m}^{3} /$ day for rice paddy with 13.5 ha. Double and triple linked water-

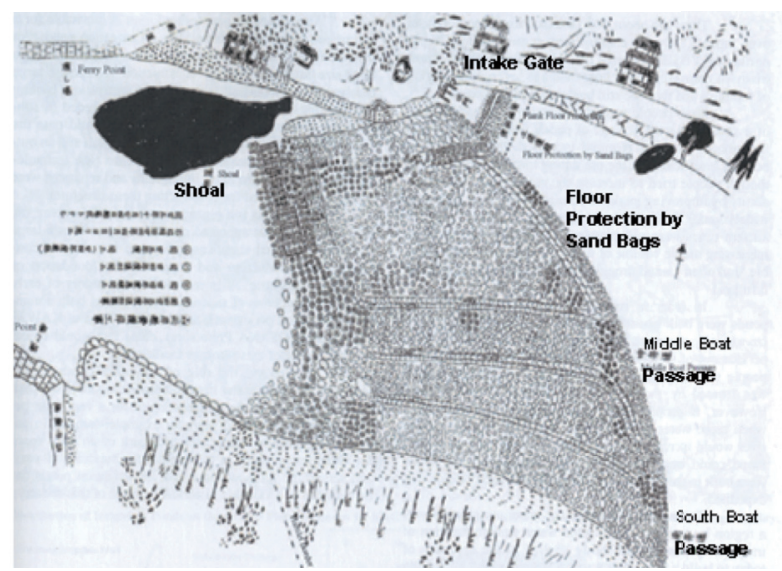

Fig. 2. Original Yamada diversion dam constructed in 1963 (SNRKK., 2004).

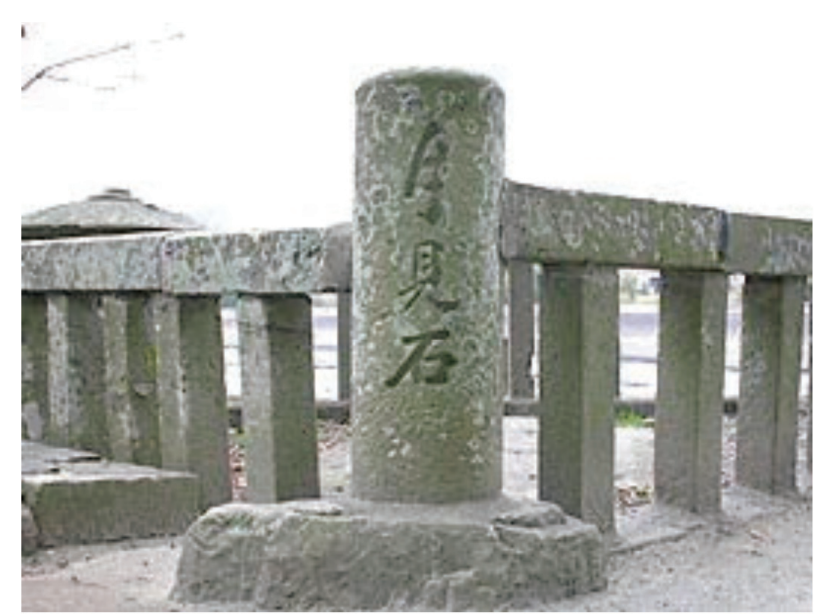

Fig. 3. Bench mark used for surveying (Fukuoka Pref., 2005).

wheels are still working for irrigating totally 35 ha rice paddy. Every five years, these wooden waterwheels are needed to be renewed.

\section{MODERNAIZED IRRIGATION SYSTEM}

The old diversion dam was seriously damaged several times as stated above. Finally this dam was reformed in 1980 with modernized technique taking into account historical structure as shown in Fig. 5. The length and width of inclined dam is $309 \mathrm{~m}$ and $47 \mathrm{~m}$, respectively. Roller gates for intake water and for evacuating sediment gravels were installed, and passages for raft and boats were remained as before. The number of farmers was 1,281 in this rice paddy command area of 664 ha. Following the traditional water right, intake water gate is opened during 20 May and 15 Oct. The maximum flow rate at irrigation season is $5 \mathrm{~m}^{3} / \mathrm{s}$ and at non irrigation season is $1.5 \mathrm{~m}^{3} / \mathrm{s}$. The water at non irrigation season is used for canal maintenance, fish culture and fire prevention.

The irregularly shaped agricultural fields were reformed into rectangle with $100 \mathrm{~m}$ times $30 \mathrm{~m}$ unit. Main and branch irrigation canals were made of concrete, and tertiary canals were made of U shaped concrete flume. Main drainage canals were made of con-

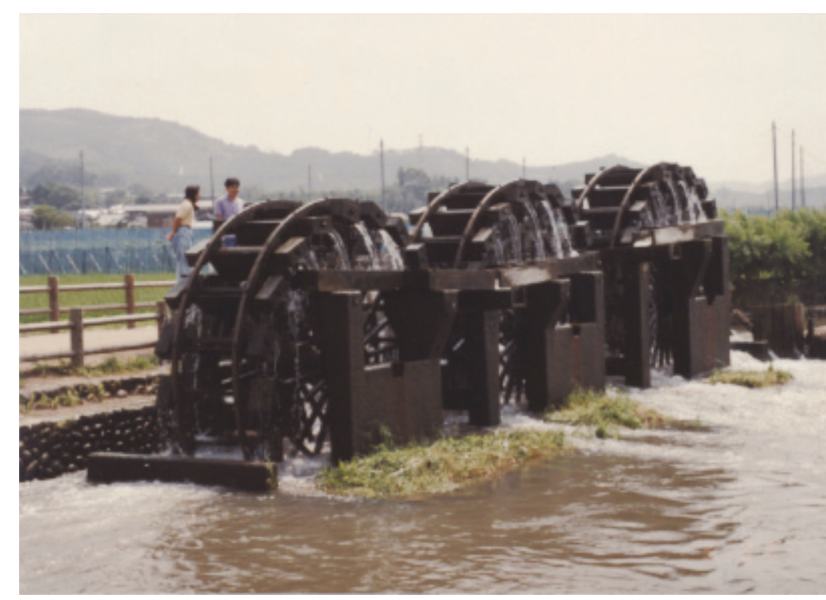

Fig. 4. Triple linked waterwheels for irrigation. 


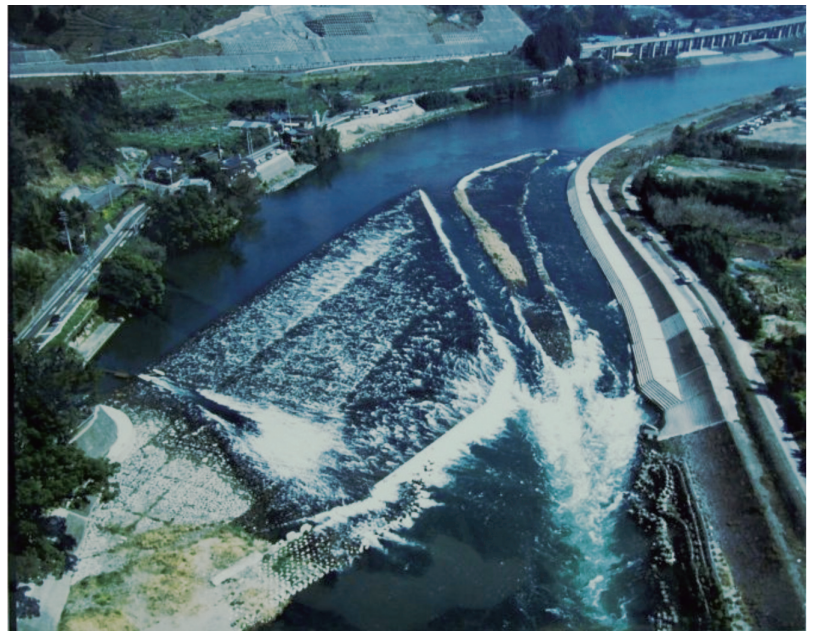

Fig. 5. Yamada diversion dam rehabilitated in 1980 (MLITJ, 2007).

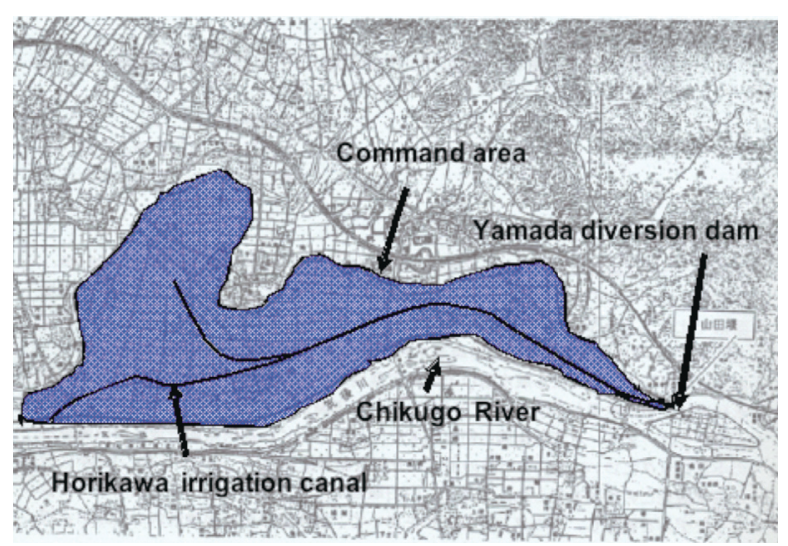

Fig. 6. Command area of the Yamada diversion dam.

crete, and branch and tertiary drainage canals were made of concrete blocks with some spaces for draining water. Main and branch irrigation and drainage canals are controlled by water user's association. The tertiary canals for both irrigation and drainage canals are controlled by framers. Basically, irrigation water is supplied by the demand priority rule.

\section{LAND USE CONDITIONS}

\section{Land use conditions in total command area}

This area is located $40 \mathrm{~km}$ in the south of big city named Fukuoka which population is over 1.4 million, and about $10 \mathrm{~km}$ in the west, a regional core city Kurume with population about 0.24 million is located. The number of farm households has been decreased as shown in Table 1. The household number has decreased about $65.4 \%$ during these 30 years. Population of farmer's family has decreased $41 \%$ during the 30 years. As shown in Table 3, total rice paddy area in 1950 was 669 ha. After land reclamation project conducted, rice paddy area increased $14.8 \%$ and decreased gradually up to $15.5 \%$ after regulation policy started in 1970 . The land consolidation brought the introduction of agricultural machine and this is resulted in the increase of the effectiveness of rice crop production. Table 2 shows the
Table 1. Number of farm households

\begin{tabular}{|c|c|c|c|c|c|c|}
\hline Years & 1970 & 1980 & 1985 & 1990 & 1995 & 2000 \\
\hline Farm household number & 1021 & 968 & 879 & 758 & 700 & 593 \\
\hline Full time farm households & 219 & 161 & 163 & 147 & 140 & 149 \\
\hline Part time farm households & & & & & & \\
\hline $\begin{array}{l}\text { Farming is main } \\
\text { occupation }\end{array}$ & 487 & 264 & 246 & 135 & 135 & 113 \\
\hline Part time farm households & & & & & & \\
\hline $\begin{array}{l}\text { Farming is not main } \\
\text { occupation }\end{array}$ & 315 & 543 & 470 & 476 & 425 & 331 \\
\hline
\end{tabular}

Table 2. Changes of rice paddy area

\begin{tabular}{lrrrrrrrrr}
\hline \multicolumn{1}{c}{ Years } & 1950 & 1960 & 1970 & 1980 & 1985 & 1990 & 1995 & 2000 \\
\hline $\begin{array}{l}\text { Paddy area (ha) } \\
\begin{array}{l}\text { Replaced to upland } \\
\text { crops }\end{array}\end{array}$ & 669 & 746 & 768 & 699 & 670 & 687 & 651 & 649 \\
$\begin{array}{l}\text { production (ha) } \\
\text { Replaced Ratio (\%) }\end{array}$ & 0.9 & 2.6 & 1.7 & 14.4 & 22.5 & 30.7 & 30.2 & 44.8 \\
\hline
\end{tabular}

land use conditions during 40 years. Before 40 years, rice production regulation was not conducted. In 2,000, the percentage of regulated rice fields became $44.8 \%$ and this value is still continuing.

\section{Land use condition in study area}

Observation block area was totally 13.76 ha. Land use conditions in 1981 and 1998 were listed in Table 3. Rice planted paddy area was decreased $23.5 \%$ during 17 years. To control rice production, there appeared ponding with no plant condition in 1998. This is effective to impede weed growing.

Table 3. Land use conditions of study area

\begin{tabular}{ccc}
\hline Years & 1981 & 1998 \\
\hline Paddy area (ha) & 13.76 & 13.76 \\
Rice planted paddy & 8.48 & 6.49 \\
Ponded with no plant & 0 & 0.7 \\
Replaced to upland crops & 4.84 & 5.67 \\
Replaced to orchard & 0.44 & 0.90 \\
Residential area (ha) & 0.40 & 0.40 \\
Roads (ha) & 0.60 & 0.60 \\
Replaced Ratio of Paddy (\%) & 35.2 & 41.2 \\
\hline
\end{tabular}

\section{WATER MANAGEMENT CHANGES IN RECENT YEARS}

\section{Observation method on water management}

The irrigation and drainage canals are shown in Fig. 7. Observation of water levels was conducted throughout the rice growth stage.

Irrigation inflow rate to the block $Q_{i n}$ is given as,

$$
Q_{\text {in }}=I_{1}+I_{2}+I_{3}
$$

Irrigation outflow rate from the block $Q_{\text {out }}$ is given as,

$$
Q_{\text {out }}=I_{4}+I_{5}
$$

Drainage inflow rate to the block $D_{i n}$ is given as,

$$
D_{i n}=D_{1}
$$

Drainage outflow rate from the block $D_{\text {out }}$ is given as,

$$
D_{\text {out }}=D_{2}+D_{3}
$$

Where $I_{1}, I_{2}, I_{3}, I_{4}$ and $I_{5}$ are flow rates in irrigation chan- 
nels. $D_{1}, D_{2}$ and $D_{3}$ are flow rates in drainage channels. The water uptake rate, Irri, to the block is determined as,

$$
\text { Irri }=Q_{\text {in }}-Q_{\text {out }}
$$

Effective rainfalls are added when rainfalls are observed. The drainage outflow rate from the block, Dblock, is determined as,

$$
\text { Dblock }=D_{\text {out }}-D_{\text {in }}
$$

The components of water requirement are evapotranspiration and seepage. Water requirement rate of one plot, $W_{\text {plotreq }}$, was determined by measuring inflow, $Q_{\text {plotin }}$, and outflow rate, $Q_{\text {plotout }}$, in one of the rice paddy fields as,

$$
W_{\text {plotreq }}=Q_{\text {plotin }}-Q_{\text {plotout }}
$$

The total requirement rate at whole block $W_{\text {blockreq }}$ was determined by multiplying the rice paddy area to $W_{\text {plotreq }}$ as,

$W_{\text {blockreq }}=W_{\text {plotreq }} \times$ Rice paddy area

The components of lot management water requirement are water for pudlling, midsummer drainage, pesticide application, fertilization, and weedkilling, etc. Additionally, excessive water of extensive farming by the part time farmers can be included in this category. The lot water requirement, Lot, was calculated as,

$$
\text { Lot }=\text { Irri }-W_{\text {blockreq }}
$$

There is a relationship between Dblock and Lot as,

Dblock = Lot + Lateral seepage rat

Therefore lateral seepage rate can be calculated by using above equations.

The component of delivery water requirement is to deliver water equally to each field, by keeping adequate water level in canals. The delivery water requirement Deliv is equal to $Q_{\text {out }}$ as,

$$
\text { Deliv }=Q_{\text {out }}
$$

First observations were conducted four growth stages during irrigation season in 1981 after 10 years of rice production regulation policy started. Second observations were conducted six growth stages in 1998. It was 17 years after first observation.

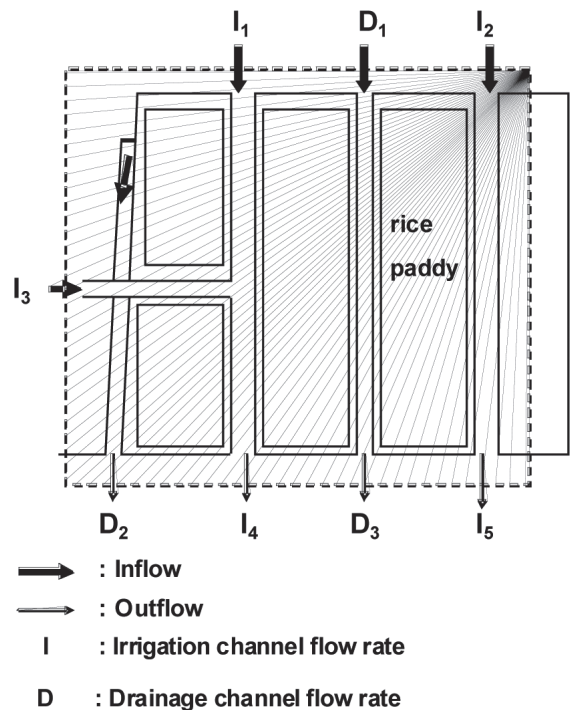

Fig. 7. Schematic view of study area.

\section{Water management characteristics in 1981}

Fig. 8 shows the water management components observed in 1981. Water consumption rates ranged from $23 \mathrm{~mm} /$ day to $53 \mathrm{~mm} /$ day. These high values were caused by the porous soil layer originated the flood of the Chikugo River. Lot water requirements were ranged from $15 \mathrm{~mm}$ /day to $27 \mathrm{~mm} /$ day. The delivery water requirements were ranged from $15 \mathrm{~mm} /$ day to $50 \mathrm{~mm} /$
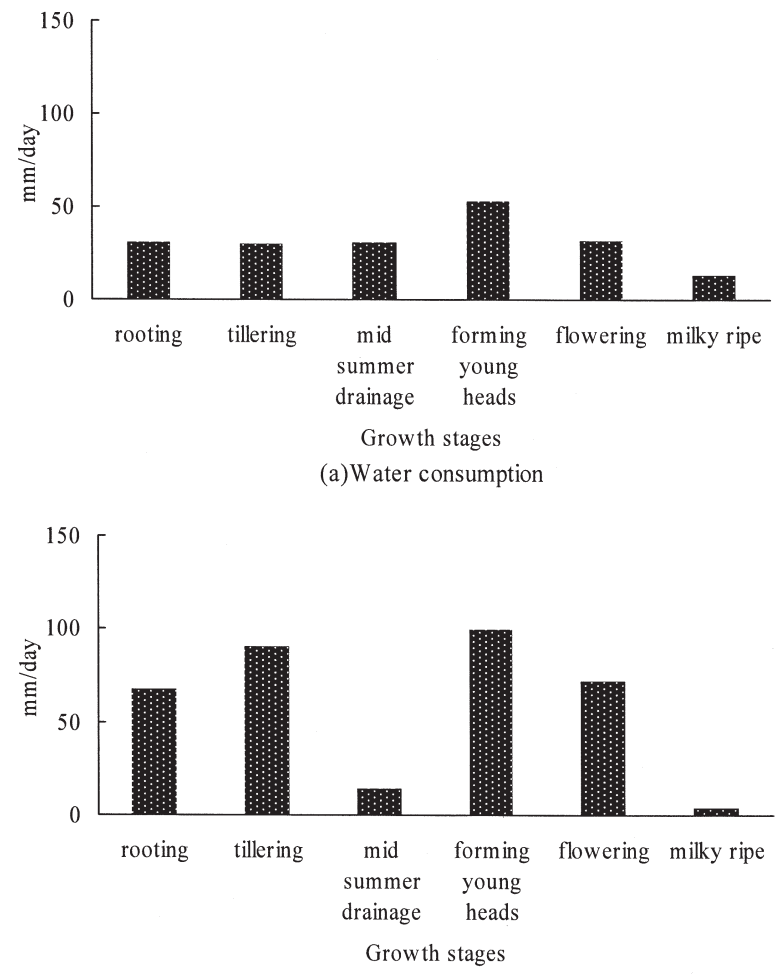

(b)Lot water requirement

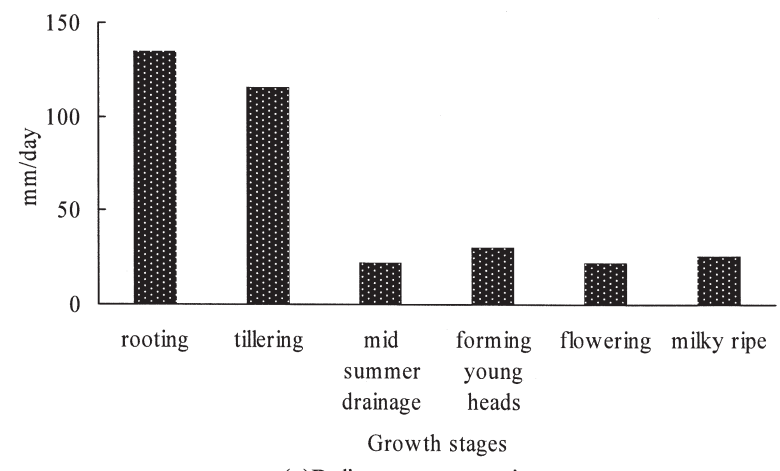

(c)Delivery water requirement

Fig. 8. Water management components in 1981.

Table 4. Water utilization components in 1981

\begin{tabular}{llccc}
\hline \multicolumn{1}{c}{ Growth stage } & Date & $\begin{array}{c}\text { Water } \\
\text { consump- } \\
\text { tion (\%) }\end{array}$ & $\begin{array}{c}\text { Lot water } \\
\text { require- } \\
\text { ment (\%) }\end{array}$ & $\begin{array}{c}\text { Delivery } \\
\text { water } \\
\text { require- } \\
\text { ment (\%) }\end{array}$ \\
\hline Rooting & 7 Jun. & 33.2 & 24.3 & 42.5 \\
Tillering & 22 Jul. & 33.7 & 22.3 & 44.0 \\
$\begin{array}{l}\text { Forming young head } \\
\text { Heading flowering }\end{array}$ & 18 Aug. & 55.7 & 20.5 & 23.8 \\
12 Sept. & 57.0 & 27.1 & 15.9 \\
\hline
\end{tabular}


day. Percentages of these three components are listed in Table 4. The percentages of water consumption, lot water requirements and delivery water requirements were ranged from $33.2 \%$ to $57 \%$, from $20.5 \%$ to $27.1 \%$ and from $15.9 \%$ to $44.0 \%$, respectively.

\section{Water management characteristics in 1998}

Fig. 9 shows the water management components observed in 1998. Water consumption rates ranged from $20 \mathrm{~mm} /$ day to $52 \mathrm{~mm} /$ day. The values were almost the same range with the observation in 1981. Lot water requirement were ranged from $5 \mathrm{~mm} /$ day to $100 \mathrm{~mm} /$ day. Delivery water requirements were ranged from $25 \mathrm{~mm} /$ day to $137 \mathrm{~mm} /$ day. It will be emphasized that the maximum values of Lot water requirements and delivery water requirements were over twice of the values in 1981. It would be the results of decreasing the rice paddy area about 23.5\%. Another reason would be decreased number of farmers. In the total command

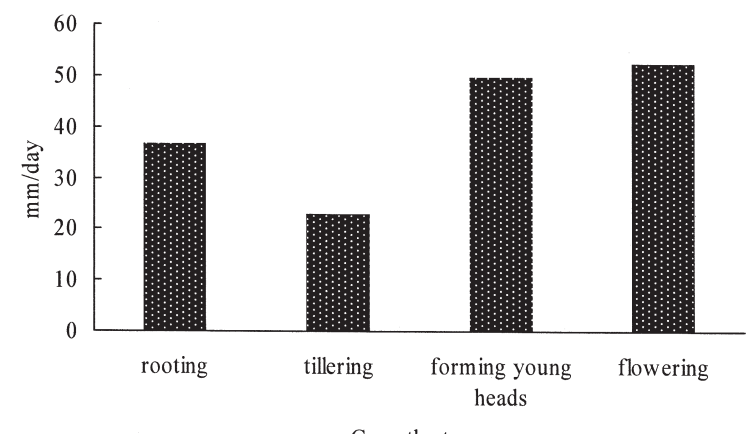

Grow th stages

(a)Water consumption

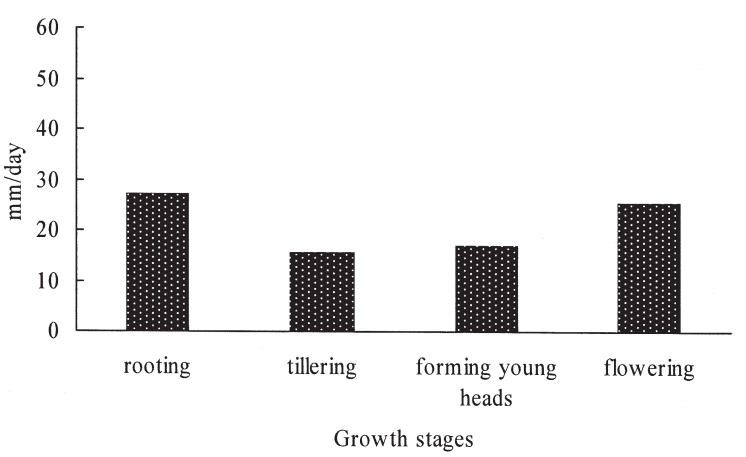

(b)Lot water requirement

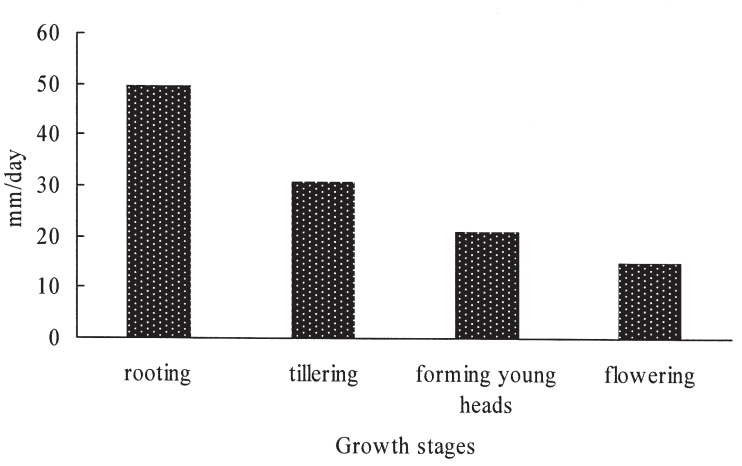

(c)Delivery water requirement

Fig. 9. Water management components in 1998.
Table 5. Water utilization components in 1998

\begin{tabular}{lcccc}
\hline \multicolumn{1}{c}{ Growth stage } & Date & $\begin{array}{c}\text { Water } \\
\text { consump- } \\
\text { tion (\%) }\end{array}$ & $\begin{array}{c}\text { Lot water } \\
\text { require- } \\
\text { ment (\%) }\end{array}$ & $\begin{array}{c}\text { Delivery } \\
\text { water } \\
\text { require- } \\
\text { ment (\%) }\end{array}$ \\
\hline Rooting & 23 Jun. & 23.5 & 29.4 & 57.1 \\
Tillering & 3 Jul. & 13.3 & 38.3 & 48.4 \\
Mid summer Drainage 24 Jul. & 44.8 & 22.7 & 32.5 \\
Forming young head & 7 Aug. & 29.2 & 54.4 & 16.4 \\
Heading flowering & 28 Aug. & 23.4 & 59.3 & 17.3 \\
Milky ripe & 18 Sept. & 32.4 & 11.5 & 56.1 \\
\hline
\end{tabular}

area, the farm household number in 1980 was 968 and this number became 593. Within 20 years, the percentages of farm household number decreased $38.7 \%$. The water demand for rough management would be caused the additional need of water. Percentages of these three components are listed in Table 5. The percentages of water consumptions, lot water requirements and delivery water requirements were ranged from $13.3 \%$ to $44.8 \%$, from $22.7 \%$ to $59.3 \%$ and from $16.4 \%$ to $57.1 \%$, respectively.

\section{Water intake rates of whole command area}

Fig. 10 shows the water intake rate at the head of command area. Most of the values in 1981 ranged from $4 \mathrm{~m}^{3} / \mathrm{s}$ to $5 \mathrm{~m}^{3} / \mathrm{s}$. These values were within the traditional water intake right $5 \mathrm{~m}^{3} / \mathrm{s}$. The values in 1998 were ranged from $5 \mathrm{~m}^{3} / \mathrm{s}$ to $6 \mathrm{~m}^{3} / \mathrm{s}$, though the observation data were not enough. It is interesting to note that the rice planted paddy area showed maximum value 755 ha in 1970 , and decreased to 358 ha in 2,000. The percentages of decreasing were $52.6 \%$ during 30 years. But the water intake rates were not changed. The excessive irrigation water would be required for and delivery water managements.

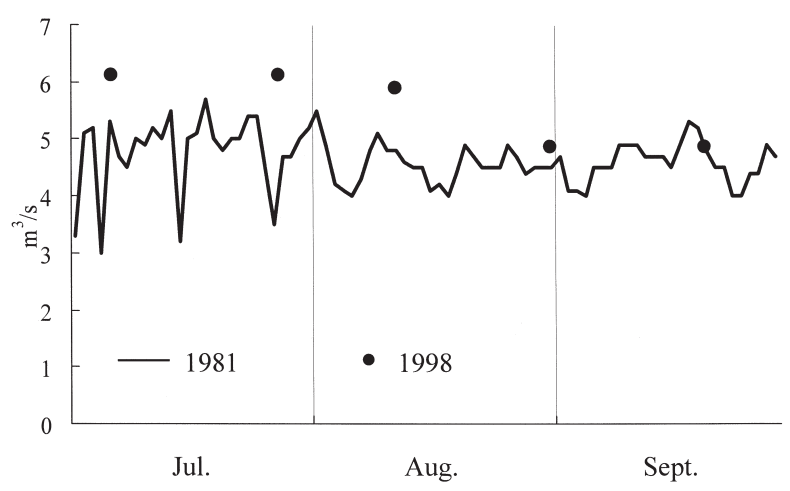

Fig. 10. Water intake rate at the head of the Yamada diversion dam.

\section{CONCLUSIONS}

Japanese rural area has been created by rice paddy culture during over 2,000 years. In $17^{\text {th }}$ century, after the long lasted civil war, many projects to develop water resources were conducted in all over Japan. The Yamada diversion dam is one of them. During 300 years 
after constructed, this dam was repeatedly damaged by the floods. Rice paddy culture has been kept and progressed by the elaborate works of farmers. But in recent years, rice culture has been affected by the regulation policy for controlling the excessive production. To clarify the recent changes of water management, a typical rural area was selected. First, historical development of rice paddy area supported by the Yamada diversion dam was studied. Second, characteristics of water management observed in 1981 and 1998 were studied. The components of lot water requirement rate and delivery water requirement have shown drastic change, though water consumption rate has shown no change. Third, water intake rate changes at the Yamada diversion dam were studied. It is intersecting to note that the reduced area of rice paddy did not affect the intake rate to this command area. This result would be caused by the need for keeping the water level in canals to deliver water equally to each rice paddy fields and by the need for supplying water to lot water management.

Recently, multifunctionality of rice paddy culture is going to be approved (Matsuno, 2006; Anan et al., 2007). The percentage of water consumption to the total intake water is low enough, but the water for lot management and water level management will be helpful for enrich the environment.

\section{ACKNOWLEDGEMENTS}

The authors express their deep appreciation to Dr. Masaharu Kuroda and Mr.Tamotsu Funakoshi for their cooperation.

\section{REFERENCES}

Anan. M, K. Yuge, Y. Nakano, T. Funakoshi and T. Haraguchi 2004 The relationship between water intake rates, paddy ponding depth, and farmers' water management techniques. Paddy and Water Environment, Vol. 2, No. 1, 11-18

Anan M., K. Yuge, Y. Nakano, S. K. Saptomo and T. Haraguchi: 2007 Quantification of the effect of rice paddy area changes on recharging groundwater, Paddy and Water Environment, Vol. 5, No. 1, 41-47

Fukuoka Prefecture 2005 Horikawa irrigation canal and Asakura waterwheels http://www.educ.pref.fukuoka.lg.jp/bunka/cgi-bin/detail/ closeup.cgi?number $=154$

Shin Nogyodoboku Rekishi Kenkyu-Kai (SNRKK) 2004, Heritage of Land Development, Maruzen, Tokyo (Japan), pp. 119

Matsuno Y., Nakayama K. Masumoto T.. Matsui H., Kato T, Sato Y; 2006 Prospects of multifunctionality of rice cultivation in Japan and other countries in monsoon Asia, Paddy and Water Environment, Vol. 4, No. 4, 189-204

Ministry of Land, Infrastructure and Transport Government of Japan (MLITG) 2007 Infrastuructures for flood control and water utilization.

http://www.qsr.mlit.go.jp/chikugo/old/chikugo/tisui/index. html 